УДК 634.8:663.2:631

DOI 10.30679/2219-5335-2021-4-70-322-335

АРОМАТОБРАЗУЮЩИЕ
ВЕЩЕСТВА В ВИНОМАТЕРИАЛАХ
ИЗ ВИНОГРАДА,
ПРОИЗРАСТАЮЩЕГО
В ДАГЕСТАНЕ

Бахмулаева Зейнаб Кадировна

канд. биол. наук

старший научный сотрудник

лаборатории биохимии

и биотехнологии

e-mail: bahmulaeva@mail.ru

Даудова Татьяна Идрисовна

старший научный сотрудник

лаборатории биохимии

и биотехнологии

e-mail: batuch@yandex.ru

Магомедов Гаджи Гасайникадиевич научный сотрудник

лаборатории биохимии

и биотехнологии

e-mail:magas1951@mail.ru

Аливердиева Динара Алиевна

канд. биол. наук

зав. лабораторией

биохимии и биотехнологии

e-mail: aliverdieva_d@mail.ru

Прикаспийский институт

биологических ресурсов

ФГБУН Дагестанского федерального

исследовательского иентра

Российской академии наук,

Махачкала, Республика Дагестан,

Россия

Шелудько Ольга Николаевна

д-р техн. наук, доцент

зав. НЦ «Виноделие»

e-mail: scheludcko.olga@yandex.ru

Якуба Юрий Федорович

д-р хим. наук, доцент

зав. информационно-

аналитической лабораторией

ЦКП «Приборно-аналитический»

e-mail: uriteodor@yandex.ru
UDC 634.8:663.2:631

DOI 10.30679/2219-5335-2021-4-70-322-335

\section{AROMA-PRODUCING \\ SUBSTANCES \\ IN WINE MATERIALS \\ FROM GRAPES GROWING \\ IN DAGHESTAN}

Bakhmulaeva Zeinab Kadirovna

Cand. Biol. Sci.

Senior Research Associate

of Biochemistry and Biotechnology

Laboratory

e-mail: bahmulaeva@mail.ru

Daudova Tatiana Idrisovna

Senior Research Associate

of Biochemistry and Biotechnology

Laboratory

e-mail: batuch@yandex.ru

Magomedov Gadji Gasaynikadievich

Research Associate

of Biochemistry and Biotechnology

Laboratory

e-mail: magas1951@mail.ru

Aliverdieva Dinara Alievna

Cand. Biol. Sci.

Head of Biochemistry

and Biotechnology Laboratory

e-mail: aliverdieva_d@mail.ru

Caspian Institute

of Biological Resources

of the Daghestan Federal

Research Center

Russian Academy Sciency,

Makhachkala, Republic of Daghestan,

Russia

Shelud'ko Olga Nikolaevna

Dr. Sci. Tech., Docent

Head of CS «Wine-making»

e-mail: scheludcko.olga@yandex.ru

Yakuba Yuriy Fedorovich

Dr. Sci. Chem., Docent

Head of the Information and Analytical

Laboratory of Center of Collective Using

«Instrumental and Analitical»

e-mail: uriteodor@yandex 
Федеральное государственное бюджетное научное учреждение «Северо-Кавказский федеральный научный иентр садоводства, виноградарства, виноделия», Краснодар, Россия

Виноградовинодельческая отрасль является приоритетной в агропромышленном комплексе Дагестана. В настоящее время, когда обращается особое внимание на создание условий для производства вин «защищенных географических наименований», необходимо расширять исследования виноградного сырья, используемого для их производства. В связи с этим в РД актуально изучение питательных и технологических свойств новых автохтонных сортов винограда, наряду с интродуцированными, для рекомендации производства из них вин, способных повысить престиж местной винодельческой продукции. Определен качественный состав и количественное содержание пулов ароматобразующих веществ в красных и розовых вин наливом, изготовленных из винограда технических местных сортов Гимра новая и Фиолетта, а также интродуцента - Первенец Магарача (урожай 2019 г.), выращиваемых в условиях Дербентского района РД на плантации Дагестанской селекционной опытной станции виноградарства и овощеводства филиала ФГБНУ СКФНЦСВВ. Ароматобразующие вещества определяли на газовом хроматографе «Кристалл 2000М» (РФ). Значительное содержание суммы карбонильных соединений $(325,48$ мг/дм²) и сложных эфиров $\left(252,94\right.$ мг/дм $\left.{ }^{3}\right)$ обнаружено в розовом вине наливом, произведенном из сортов Первенец Магарача и Фиолетта. Наибольшее суммарное количество высших спиртов $\left(1871,37\right.$ мг/дм $\left.{ }^{3}\right)$ и ароматических компонентов $(2588,68$ мг/дм³ $)$ выявлено в вине наливом из красного сорта Гимра новая. Отмечена высокая концентрация
Federal State Budget

Scientific Institution

"North Caucasian Federal

Scientific Center of Horticulture, Viticulture, Wine-making», Krasnodar, Russia

The grape-growing industry is a priority in the agro-industrial complex of Daghestan. At present, when special attention is paid to creating conditions for the production of "protected geographical indication" wines, it is necessary to expand the research of grape raw materials used for their production. In this regard, in the Republic of Daghestan the study of nutritional and technological properties of new autochthonous grape varieties, along with introduced ones is actual, to recommend the production of wines from them that can increase the prestige of local wine products. It is determined that the qualitative composition and quantitative content of pools of aroma-producing substances in red and rose wine materials made from grapes of technical local varieties Gimra Novaya and Fioletta, as well as the Pervenets Magaracha (harvest 2019), grown in the conditions of the Derbent district of the Republic of Daghestan on the plantation of the Dagestan Selecting Testing Station of Viticulture and Horticulture - branch of the Federal State Budget Scientific Institution «North Caucasian Federal Scientific Center of Horticulture, Viticulture, Winemaking». Aroma-producing substances were determined on a gas chromatograph «Crystal 2000M» (RF). A significant amount of carbonyl compounds $\left(325.48 \mathrm{mg} / \mathrm{dm}^{3}\right)$ and esters $\left(252.94 \mathrm{mg} / \mathrm{dm}^{3}\right)$ was found in the rose wine material produced from the Pervenets Magaracha and Fioletta varieties. The highest total number of higher alcohols $\left(1871.37 \mathrm{mg} / \mathrm{dm}^{3}\right)$ and aromatic components $\left(2588.68 \mathrm{mg} / \mathrm{dm}^{3}\right)$ was found in the wine material from the red variety Gimra Novaya. 
2,3 бутиленгликоля и высшего спирта изоамилового спирта.

Суммарная массовая концентрация летучих кислот в изученных опытных образцах вин наливом составляла 439,56-781,28 мг/дм³. Определено, что природные условия южной зоны Дагестана благоприятны для культивирования винограда автохтонных сортов Гимра новая, Фиолетта и интродуцированного Первенец Магарача. Использование их в виде сырья для получения вин наливом высокого качества позволит сформироваться в их букете тонам дымного чернослива, оттенкам вкуса плодов граната и терна.

Ключевые слова: СОРТА ВИНОГРАДА, ГИМРА НОВАЯ, ФИОЛЕТТА, ПЕРВЕНЕЦ МАГАРАЧА, ВИНО НАЛИВОМ, АРОМАТОБРАЗУЮЩИЕ ВЕЩЕСТВА
A high concentration of 2,3 butylene glycol and a higher alcohol, isoamyl alcohol, was noted. The total mass concentration of volatile acids in the studied experimental samples of wine materials was $439.56-781.28 \mathrm{mg} / \mathrm{dm}^{3}$. It is determined that the natural conditions of the southern zone of Daghestan are favourable for the cultivation of grapes of autochthonous varieties Gimra Novaya, Fioletta and introduced variety Pervenets Magaracha. Using them as raw materials for obtaining high-quality wine materials will allow you to form in their bouquet the tones of smoky prunes, hints of the taste of pomegranate and blackthorn fruits.

Key words: GRAPE VARIETIES, GIMRA NOVAYA, FIOLETTA, PERVENETS MAGARACHA, WINE MATERIAL, AROMA-PRODUCING SUBSTANCES

Введение. В Дагестане, закономерно имеющем статус одного из основных производителей виноградовинодельческой продукции в России, обладающем обширными площадями под виноградными плантациями с разнообразным сортовым составом и большим аборигенным генетическим потенциалом, на сегодняшний день производится незначительное количество вин из местных сортов винограда.

Очевидно, что в настоящее время, когда создаются условия для производства вин, закреплённых под терминами - «вина защищенных географических указаний» и «вина защищенных наименований места происхождения» открывается перспектива, способствующая повышению престижа вин, выпускаемых в Дагестане. Назрела необходимость наряду с интродуцированными сортами, практически составляющими наибольшую часть сортимента выращиваемого в Республике винограда, обратить внимание на возрождение культуры автохтонных (местных) технических сортов, так как 
с их использованием связана возможность производства высококачественных, уникальных вин, способных прославить виноградарство и виноделие республики [1].

Цель работы - исследование ароматобразующего комплекса вин наливом, полученных из винограда автохтонных технических сортов Гимра новая, Фиолетта и интродуцированного сорта Первенец Магарача, выращиваемых в природных условиях южной равнинной зоны Дагестана.

Объекты и методы исследований. Определяли качественный состав и количественное содержание ароматобразующих веществ в опытных образцах вин наливом, изготовленных из винограда автохтонных сортов Гимра новая, Фиолетта и интродуцированного сорта Первенец Магарача, произрастающего на опытных участках виноградника, расположенного на территории Дагестанской селекционной опытной станции виноградарства и овощеводства (ДСОСВИО) филиала ФГБНУ СКФНЦСВВ.

Культура винограда - корнесобственная, орошаемая, неукрывная. Форма кустов - высокоштамбовая (120 см), двуплечий кордон Казенава. Все насаждения на вертикальной проволочной шпалере.

Почвы под посадками исследуемого винограда - светло-каштановые, суглинистые, тяжелого и среднего механического состава, бесструктурные, видоизмененные из-за длительного использования как плантации. Содержание гумуса в почве на опытных участках низкое, обеспеченность её подвижным фосфором очень низкая, а обменным калием низкая и средняя.

Среднегодовая температура воздуха на винограднике, по данным Дагестанского центра по гидрометеорологии и мониторингу окружающей среды, равна $14,7^{\circ} \mathrm{C}$. Самый теплый месяц - август $\left(27,2^{\circ} \mathrm{C}\right)$, самый холодный - январь $\left(2,8{ }^{\circ} \mathrm{C}\right)$, отрицательные среднемесячные температуры не наблюдаются. Продолжительность периода с температурой воздуха $10{ }^{\circ} \mathrm{C}$ 
и выше составляет 230 дней. Безморозный период длится 249 дней, с температурой выше $10^{\circ} \mathrm{C}$ в период интенсивного роста - 203 дня, максимальная температура воздуха - 35, $6^{\circ} \mathrm{C}$ (август).

Оптимальное количество атмосферных осадков, благоприятствующих нормальной жизнедеятельности виноградного куста, составляло 388,1 мм в год. Характерной особенностью природных условий в Дербентском районе РД, где проводились исследования, является общая засушливость климата, причем наименьшее количество осадков здесь выпадает в летний период за время интенсивного роста виноградного куста (V-VIII) 128,4 мм. Гидротермический коэффициент летом опускается до 0,2, что указывает на необходимость орошения виноградных насаждений.

Для получения опытных образцов вин наливом виноград перерабатывали в лабораторных условиях по технологическим схемам, соответствующим типу вина. Сусло для получения вин наливом отстаивали в течение 10-12 часов, с введением диоксида серы из расчета 60 мг/дм³ и сбраживали. По окончании брожения и осветления вина наливом снимали с дрожжевого осадка.

Ароматобразующие компоненты в опытных образцах вин наливом определяли на газовом хроматографе «Кристалл 2000М» (РФ) [2]. Результаты обрабатывали с помощью Multichrome для Windows версии 1.5 и статистических программ для Windows.

Обсужнение результатов. Одним из признаков, определяющих качество вин, как известно, является их приятный аромат, с сохраненными нюансами запаха ягод различных сортов винограда, использованного при производстве вин наливом.

Ароматобразующие вещества, участвующие в формировании аромата или букета вина, являются продуктами спиртового брожения и представ- 
лены в нем альдегидами, ацеталями, высшими спиртами, сложными эфирами и другими веществами. Одни из них ответственны за общий винный аромат, другие - за его специфические оттенки в различных типах вин. Состав ароматических веществ винограда и вин сложен и многообразен. В настоящее время известно более 350 соединений, обусловливающих ароматические свойства винограда и продуктов его переработки. Аромат вина зависит от сорта, почвенно-климатических условий произрастания винограда, штаммов дрожжей, вызывающих брожение сусла и методов виноделия [3-12]. Комплекс веществ, участвующий в образовании аромата вина, весьма нестойкий, и со временем в результате окислительно-восстановительных процессов, протекающих в вине, изменяется [13, 14].

При окислении спиртов образуются альдегиды. Из алифатических и ароматических альдегидов 90 \% по массе приходится на ацетальдегид. Повышенное содержание альдегидов в вине ухудшает его аромат, но присутствие их в небольших количествах обуславливает появление тонов различных фруктов. Альдегиды характеризуются низким порогом восприятия вкуса и почти полным отсутствием посторонних привкусов. Во всех исследуемых опытных образцах вин наливом среди карбонильных соединений больше всего накопилось ацетальдегида [15].

Наибольшая концентрация ацетальдегида обнаружена в розовом вине наливом из винограда сортов Первенец Магарача и Фиолетта, которая была в 4,6 и 6,6 раза выше, чем в красных винах наливом из сортов Фиолетта и Гимра новая соответственно (табл. 1).

Этилацеталь придает вину приятные тона плодового аромата. Содержание его в розовых винах наливом составило 1,93 и 2,59 мг/дм². К фурановым альдегидам относится фурфурол, образование которого происходит из пентоз, содержащихся в вине. При брожении сусла концентрация фурановых альдегидов изменяется мало. Содержится он в винограде от 0,5 до 25 мг/дм³ ${ }^{3}$ Количество фурфурола, участвующего в образовании букета 
вин, в опытных образцах составляло 6,64-13,09 мг/дм³. Наибольшее содержание его обнаружено в розовом вине из сортов Первенец Магарача и Гимра новая.

Таблица 1 - Карбонильные соединения и сложные эфиры в опытных образцах вин наливом из винограда, выращиваемого в Дагестане

\begin{tabular}{|c|c|c|c|c|}
\hline \multirow{2}{*}{ Компонент } & \multicolumn{4}{|c|}{$\begin{array}{c}\text { Опытные образцы вин наливом, } \\
\text { концентрация карбонильных соединений и сложных эфиров, мг/дм }\end{array}$} \\
\hline & Фиолетта & Гимра новая & $\begin{array}{c}\text { Первенец Магарача } \\
+ \text { +Фиолетта }\end{array}$ & $\begin{array}{l}\text { Первенец Магарача } \\
+ \text { +Гимра новая }\end{array}$ \\
\hline Ацетальдегид & 55,71 & 38,98 & 255,44 & 70,78 \\
\hline Этилацеталь & - & - & 2,59 & 1,93 \\
\hline Фурфурол & 6,64 & - & 9,64 & 13,09 \\
\hline Каприновый & - & - & 22,91 & - \\
\hline $\begin{array}{l}\text { альдегид } \\
\text { Диашетип }\end{array}$ & & & 1448 & \\
\hline Ацетоин & 41,72 & 11,45 & 20,42 & 24,39 \\
\hline $\begin{array}{l}\text { Сумма } \\
\text { карбонильных } \\
\text { соединений }\end{array}$ & 104,07 & 50,43 & 325,48 & 110,19 \\
\hline Метилацетат & 15,44 & 5,36 & 136,53 & 19,12 \\
\hline Этилацетат & 169,34 & 82,36 & 94,14 & 78,55 \\
\hline Изоамилацетат & - & - & 0,58 & - \\
\hline Этилкапроат & - & 7,09 & 7,39 & 3,87 \\
\hline Этиллактат & - & 0,71 & 1,66 & 1,39 \\
\hline Этилкапринат & 2,13 & - & 5,26 & 9,08 \\
\hline Этилкаприлат & - & - & 0,31 & - \\
\hline Этиллаурат & 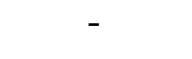 & - & 7,07 & - \\
\hline $\begin{array}{l}\text { Сумма } \\
\text { сложных } \\
\text { эфиров }\end{array}$ & 186,91 & $\mathbf{9 5 , 5 2}$ & 252,94 & 112,01 \\
\hline
\end{tabular}

Примечание: приведены результаты 3-х независимых определений

Каприновый альдегид способствует появлению приятного фруктового тона в аромате вин. Он оказался в числе компонентов в букете розового вина наливом из сортов Первенец Магарача и Фиолетта, где его массовая концентрация составляла 22,91 мг/дм³ .

Известно, что в винах присутствует простейший дикетон - диацетил и ацетоин, которые способны окисляться и разлагаться до уксусной кислоты 
[16]. Кетоны присутствуют в винограде и вине в количестве, достигающем

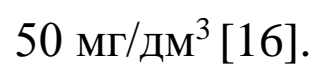

Диацетил образуется при окислении ацетоина и характеризуется ароматом лесного ореха. При содержании в винах в большом количестве он привносит приятные сливочные тона, ассоциирующиеся с молоком [16]. Однако необходимо учитывать, что наряду с положительным влиянием простейших дикетонов, образование значительного количества ацетоина и диацетила обусловливает появление тонов окисленности [16]. Диацетил обнаружен только в розовом вине наливом из сортов Первенец Магарача и Фиолетта в количестве 14,48 мг/дм³

Ацетоин, в свою очередь, образуется при разложении солей органических кислот - пирувата, лактата, цитрата. Содержание его в изученных нами образцах составило 11,45-41,72 мг/дм³. Наибольшая суммарная концентрация карбонильных соединений - 325,48 мг/дм³ - обнаружена в розовом вине наливом из сортов Первенец Магарача и Фиолетта.

Во время брожения под действием ферментов дрожжей при взаимодействии карбоновых кислот и спиртов образуются сложные эфиры. Они могут также переходить в вино из винограда при настаивании или брожении сусла на мезге. В этих случаях происходит диффузия эфиров из кожицы ягод в сок [17]. Большинство эфиров обладает приятным фруктовым ароматом [18].

Все изученные образцы вин наливом содержали метилацетат, этилацетат и этиллактат (табл. 1). Среди них превалировал этилацетат, концентрация которого оказалась в два раза больше в вине наливом из красного сорта Фиолетта - 169,34, по сравнению с розовым, изготовленным с использованием сортов Первенец Магарача и Гимра новая - 78,55 мг/дм². Этилацетат, участвует в формировании приятных ароматов: цветочного, медового и фруктового с цитрусовыми тонами. Высокие концентрации этилацетата нежелательны - содержание, превышающее 180 мг/дм³ , способствует появ- 
лению в букете посторонних тонов, идентичных запаху, создаваемому летучими кислотами [19]. В винах, произведенных в Испании из винограда красных сортов Кайньо браво, Кайньо лонго и Кайньо тинто, этиацетат содержался в концентрациях 58,91; 69,21 и 125,57 мг/дм³ [9].

Этиллактат в сочетании с молочной кислотой и этиловым спиртом создают впечатление, ассоциируемое с ароматами сливок и кокоса, придавая «округлость» фруктовым тонам. Концентрация его в красном и розовых винах наливом варьировала в пределах от 0,71 до 1,66 мг/дм³.

Этиллаурат, обладающий сладким, сливочным ароматом с цветочными оттенками, обнаружен только в вине наливом, изготовленном из сортов Первенец Магарача и Фиолетта - 7,07 мг/дм³.

Во всех исследованных винах наливом, кроме образца Гимра новая, выявлен этилкапринат (2,13-9,08 мг/дм³), влияющий на появление в ароматах вин цветочных тонов.

Изоамилацетат, создающий запах грушевой эссенции, определен только в розовом вине наливом, полученном из сортов Первенец Магарача и Фиолетта - 0,58 мг/дм³ ${ }^{3}$ В этом же опытном образце обнаружено наибольшее суммарное количество всех обнаруженных сложных эфиров - 252,94 мг/дм³.

Высшие спирты, обладая различного рода ароматом и вкусом, влияют на сложение букета и органолептическую характеристику вин. Чрезмерные концентрации высших спиртов могут привести к формированию неприятного острого запаха [20, 21].

Среди высших спиртов в исследованных опытных образцах вин наливом лидировал изоамиловый спирт (табл. 2). В опытных образцах отмечено высокое содержание 2,3-бутиленгликоль (см. табл. 2). Спирт 2,3-бутиленгликоль накапливается в субстрате при восстановлении ацетоина во время брожения и в определенных концентрациях оказывает положительное влияние на вкус и аромат вин, придавая ему тонкий плодовый оттенок и нюансы, напоминающие запах миндаля, а также привносит во вкус вина 
Плодоводство и виноградарство Юга России № 70(4), 2021 г.

элементы гармонии.

Таблица 2 - Высшие спирты, 2,3 бутиленгликоль и летучие кислоты в опытных образцах вин наливом из винограда, выращиваемого в Дагестане

\begin{tabular}{|c|c|c|c|c|}
\hline \multirow[b]{2}{*}{ Компонент } & \multicolumn{4}{|c|}{$\begin{array}{c}\text { Наименование опытного образца, } \\
\text { содержание высших спиртов и летучих кислот, мг/дм³ }\end{array}$} \\
\hline & Фиолетта & $\begin{array}{l}\text { Гимра } \\
\text { новая }\end{array}$ & $\begin{array}{c}\text { Первенец Магарача } \\
\text { + Фиолетта }\end{array}$ & $\begin{array}{c}\text { Первенец Магарача } \\
+ \text { Гимра новая }\end{array}$ \\
\hline 2-пропанол & 1,27 & - & 0,60 & - \\
\hline 1-пропанол & 5,67 & 12,90 & 10,18 & 6,42 \\
\hline Изобутанол & 59,01 & 66,87 & 81,51 & 59,03 \\
\hline 1-бутанол & - & 2,00 & - & - \\
\hline 2,3-бутиленгликоль м. & 199,79 & 494,84 & 125,80 & 192,95 \\
\hline 2,3-бутиленгликоль p. & 445,65 & 925,72 & 169,57 & 447,41 \\
\hline Изоамиловый спирт & 198,03 & 231,27 & 275,78 & 247,80 \\
\hline 1-гексанол & 7,95 & 3,74 & 10,47 & 11,52 \\
\hline 1,2-пропиленгликоль & 35,22 & 63,48 & 15,26 & 45,08 \\
\hline Фелилэтанол & 69,31 & 70,55 & 65,22 & 94,56 \\
\hline Уксусная & 775,10 & 564,63 & 431,03 & 738,78 \\
\hline Пропионовая & 3,62 & 4,69 & 1,69 & 10,37 \\
\hline Изомасляная & 2,56 & 2,04 & 2,54 & 0,01 \\
\hline Масляная & - & - & 1,83 & - \\
\hline Изовалерьяновая & - & - & 2,47 & 2,38 \\
\hline $\begin{array}{l}\text { Сумма летучих } \\
\text { кислот }\end{array}$ & 781,28 & 571,36 & 439,56 & 751,54 \\
\hline
\end{tabular}

Примечание: приведены результаты 3-х независимых определений

Ароматические спирты в исследованных винах наливом представлены 1,2-пропиленгликолем и фенилэтанолом, формирующимся в основном из аминокислот фенилаланина и тирозина и привносящим в аромат вина цветочномедовые тона, напоминающие запах шиповника, а также цветов розы и липы.

В работе [22] приведены результаты исследований красных сухих вин, приготовленных из винограда сортов Каберне-Совиньон, Саперави, Мерло, выращиваемых в Таманской зоне Краснодарского края, в которых содержание фенилэтанола составляло 11,3-19,9 мг/дм³. В наших красных винах наливом из винограда сортов Фиолетта и Гимра новая концентрация фенилэтанола была значительно выше и составила соответственно 69,31 и 70,55 мг/дм³. 
Помимо ароматических спиртов в опытных образцах вин наливом содержались летучие кислоты, также участвующие в сложении аромата. При брожении происходит накопление кислот, например, количество уксусной кислоты увеличивается в 20-25 раз (в зависимости от температуры, расы дрожжей, системы аэрации). В процессе выдержки вин, уксусная кислота постепенно накапливается в результате окисления этанола [23].

В состав летучих компонентов всех опытных образцов вин наливом входили уксусная, пропионовая и изомасляная кислоты (см. табл. 2). Масляная кислота обнаружена только в образце из сортов Первенец Магарача и Фиолетта, изовалерьяновая - в розовых винах наливом.

Суммарное содержание ароматобразующих веществ в винах наливом варьировало от 1772,37 до 2588,68 мг/дм² ${ }^{3}$ причем наибольшее выявлено в вине наливом из винограда Гимра новая, а минимальное - в опытном образце, изготовленном из сортов Первенец Магарача и Фиолетта (рис.).

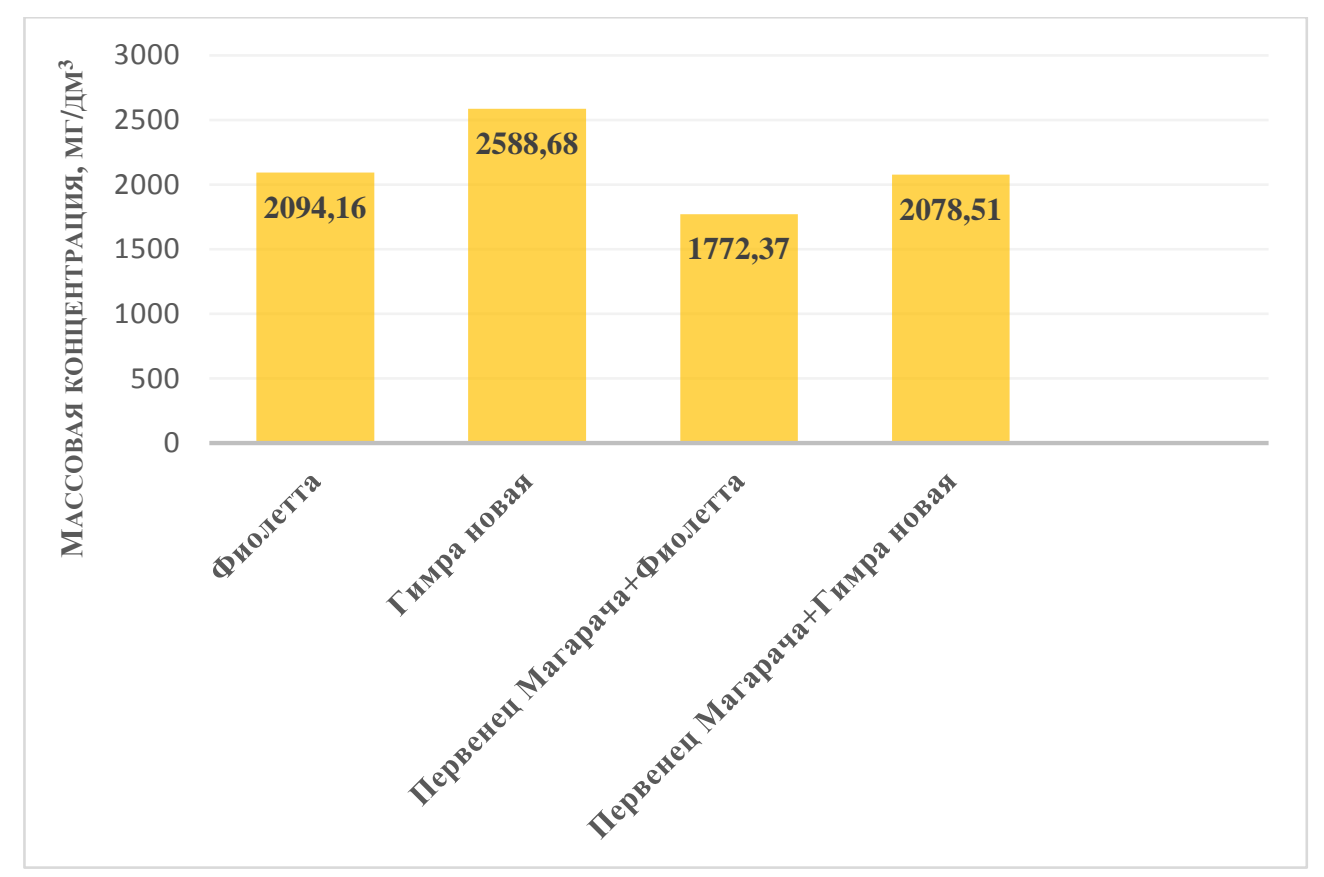

Рис. Суммарное содержание ароматических веществ в винах наливом из сортов винограда, выращиваемых в Дагестане 
Плодоводство и виноградарство Юга России № 70(4), 2021 г.

Bbыводы. В результате проведенной работы обнаружено, что в опытных образцах красных и розовых вин наливом, приготовленных из винограда автохтонных сортов Гимра новая и Фиолетта, а также интродуцированного сорта Первенец Магарача, выращиваемых в природных условиях южной зоны Дагестана, содержатся карбонильные соединения, сложные эфиры, высшие спирты и летучие кислоты. По суммарному накоплению ароматобразующих веществ первенствовало вино наливом из красного сорта Гимра новая. Результаты исследований показали, что новые технические сорта винограда Гимра новая и Фиолетта, созданные на ДСОСВиО г. Дербент, наряду с интродуцированным сортом Первенец Магарача, являются перспективным сырьем для получения вин высокого качества с чистым, свежим сортовым ароматом, полным вкусом, приятным ягодным послевкусием, с нюансами терна, дымного чернослива и плодов граната.

\section{Литература}

1. Наумова Л.Г., Ганич В.А., Матвеева Н.В. Изучение дагестанских аборигенных технических сортов винограда в условиях нижнего Придонья // Русский виноград. 2015.T. 2. C. $12-18$.

2. Якуба Ю.Ф., Темердашев З.А. Хроматографические методы в анализе и идентификации виноградных вин // Аналитика и контроль. 2015. Т. 19. № 4. С. 288-301.

3. Belda I., Ruiz J., Esteban-Fernández A., Navascues E. Microbial contribution to wine aroma and its intended use for wine quality improvement // Molecules, 2017. Vol. 22. N 2. P. $189-217$.

4. Pretorius I. S. Tasting the terroir of wine yeast innovation. Mini review // FEMS Yeast Research. 2020. Vol. 20. N 1. P. 1-22. DOI: 10.1093/femsyr/foz084.

5. Дергунов А.В., Лопин С.А., Ильяшенко О.М., Гугучкина Т.И., Якименко Е.Н. Влияние сортовых особенностей винограда на биохимические составляющие и качество вин // Виноделие и виноградарство. 2014. № 2. С. 16-20.

6. Cheng, G. Comparison between aroma compounds in wines from four Vitis vinifera grape varieties grown in different shoot positions // Food Science and Technology. Campinas. 2015. Vol. 35(2). P. 237-246.

7. Yusen $\mathrm{Wu}$ Y. Shiping Wang Aroma characterization based on aromatic series analysis in table grapes // Scientific Reports. 2016. Vol. 6. P. 31116-31132.

8. Imre S. P., Kilmartin P. A., Rutan T., Mauk J. L., Nicolau L. Influence of soil geochemistry on the chemical and aroma profiles of pinot noir wines // Journal of food agriculture and environment. 2012. Vol. 10. N 2. P. 280-288.

9. Vilanova M., Cortés S., Santiago J.L., Martínez C., Esperanza Fernández E. Aromatic compounds in wines produced during fermentation: Effect of three red cultivars // International journal of food properties. 2007. Vol. 10. N 4. P. 867-875. DOI: 


\subsection{0/10942910601161615.}

10. Guo C., Ye L., Tai-X. Y, Zhen-Wen Z. Comparison between aroma compounds in wines from four Vitis vinifera grape varieties grown in different shoot positions // Food science and technology. 2015. Vol. 35. N2. DOI: 10.1590/1678-457X.6438.

11. Petronilho S., Lopez R., Ferreira V., Coimbra M. A., Sílvia M., Rocha S. M. Revealing the usefulness of aroma networks to explain wine aroma properties: A case study of portuguese wines // Molecules. 2020. Vol. 25. N 272. DOI:10.3390/molecules25020272.

12. Styger G., Prior B., Bauer F. F. Wine flavor and aroma // Journal of Industrial Microbiology. 2011. Vol. 38. N 9. P. 1145-1159. DOI: 10.1007/s10295-011-1018-4.

13. Francis I. L., Newton J. L. Determining wine aroma from compositional data. // Australian Journal of Grape and Wine Research. 2005. Vol. 11. Issue 2. P. 114-126.

14. Sarrazin E. D., Dubourdieu P., Sarrazin E. Darriet Characterization of key-aroma compounds of botrytized wines, influence of grape botrytrzatron // Food chemistry. 2007. Vol. 103.Issue 2. P. 536-545.

15. Рибейро-Гайон Ж., Пейно Э., Рибейро-Гайон П. Теория и практика виноделия. Способы производства вин. Превращения в винах. М.: Пищевая пром-ть, 1980. Т. 3. $462 \mathrm{c}$.

16.Виноградные вина, проблемы оценки их качества и региональной принадлежности / Якуба Ю.Ф. [и др.] // Аналитика и контроль. 2014. Т. 18. № 4. С. 344-372.

17. Соболев Э. М. Технология натуральных и специальных вин. Майкоп: ГУРИПП «Адыгея», 2004. 400 с.

18. Sumby K. M., Grbin P. R., Jiranek V. Microbial modulation of aromatic esters in wine:Current knowledge and future prospects // Food Chemistry. 2010. Vol. 121. P. 1-16.

19. Кишковский 3.Н., Мержаниан А.А. Технология вина. М.: Легкая и пищ. промть, 1994. 504 с.

20. Yang E. Dourtoglou Approaches to outline the aromatic profile of Kyoho wines from South Korea // Bio web f Conferences. 40 th World Congressof Vine and Wine. 2017. Vol. 9. P. 2034-2038.

21. Duan L. L. Effects of AddingUnsaturated Fatty Acids on Fatty AcidComposition of Saccharomyces cerevisiaeand Major Volatile Compounds in Wine // S. Afr. J. Enol. Vitic. 2015. Vol. 36. P. 285-295.

22. Якименко Е.Н., Агеева Н.М., Якуба Ю.Ф. Биохимический состав столовых вин в зависимости от сорта винограда // Научные труды СКФНЦСВВ. Т. 25. Краснодар: СКФНЦСВВ, 2019. С. 196-200.

23. Ильчибаева И.Б. Технологическое значение органических соединений в виноделии. Новочеркасск: ЮРГТУ, 2007. 112 с.

\section{References}

1. Naumova L.G., Ganich V.A., Matveeva N.V. Izuchenie dagestanskih aborigennyh tekhnicheskih sortov vinograda v usloviyah nizhnego Pridon'ya // Russkij vinograd. 2015. T. 2. S. 12-18.

2. Yakuba Yu.F., Temerdashev Z.A. Hromatograficheskie metody v analize i identifikacii vinogradnyh vin // Analitika i kontrol'. 2015. T. 19. № 4. S. 288-301.

3. Belda I., Ruiz J., Esteban-Fernández A., Navascues E. Microbial contribution to wine aroma and its intended use for wine quality improvement // Molecules, 2017. Vol. 22. N 2. P. 189-217.

4. Pretorius I. S. Tasting the terroir of wine yeast innovation. Mini review // FEMSYeast Research. 2020. Vol. 20. N 1. P. 1-22. DOI: 10.1093/femsyr/foz084. 
5. Dergunov A.V., Lopin S.A., Il'yashenko O.M., Guguchkina T.I., Yakimenko E.N. Vliyanie sortovyh osobennostej vinograda na biohimicheskie sostavlyayushchie i kachestvo vin // Vinodelie i vinogradarstvo. 2014. № 2. S. 16-20.

6. Cheng, G. Comparison between aroma compounds in wines from four Vitis vinifera grape varieties grown in different shoot positions // Food Science and Technology. Campinas. 2015. Vol. 35(2). P. 237-246.

7. Yusen $\mathrm{Wu}$ Y. Shiping Wang Aroma characterization based on aromatic series analysis in table grapes // Scientific Reports. 2016. Vol. 6. P. 31116-31132.

8. Imre S. P., Kilmartin P. A., Rutan T., Mauk J. L., Nicolau L. Influence of soil geochemistry on the chemical and aroma profiles of pinot noir wines // Journal of food agriculture and environment. 2012. Vol. 10. N 2. P. 280-288.

9. Vilanova M., Cortés S., Santiago J.L., Martínez C., Esperanza Fernández E. Aromatic compounds in wines produced during fermentation: Effect of three red cultivars // International journal of food properties. 2007. Vol. 10. N 4. P. 867-875. DOI: 10.1080/10942910601161615.

10. Guo C., Ye L., Tai-X. Y, Zhen-Wen Z. Comparison between aroma compounds in wines from four Vitis vinifera grape varieties grown in different shoot positions // Food science and technology. 2015. Vol. 35. N2. DOI: 10.1590/1678-457X.6438.

11. Petronilho S., Lopez R., Ferreira V., Coimbra M. A., Sílvia M., Rocha S. M. Revealing the usefulness of aroma networks to explain wine aroma properties: A case study of portuguese wines // Molecules. 2020. Vol. 25. N 272. DOI:10.3390/molecules25020272.

12. Styger G., Prior B., Bauer F. F. Wine flavor and aroma // Journal of Industrial Microbiology. 2011. Vol. 38. N 9. P. 1145-1159. DOI: 10.1007/s10295-011-1018-4.

13. Francis I. L., Newton J. L. Determining wine aroma from compositional data. // Australian Journal of Grape and Wine Research. 2005. Vol. 11. Issue 2. P. 114-126.

14. Sarrazin E. D., Dubourdieu P., Sarrazin E. Darriet Characterization of key-aroma compounds of botrytized wines, influence of grape botrytrzatron // Food chemistry. 2007. Vol. 103.Issue 2. P. 536-545.

15. Ribejro-Gajon Zh., Pejno E., Ribejro-Gajon P. Teoriya i praktika vinodeliya. Sposoby proizvodstva vin. Prevrashcheniya v vinah. M.: Pishchevaya prom-t', 1980.T. 3. $462 \mathrm{~s}$.

16. Vinogradnye vina, problemy ocenki ih kachestva i regional'noj prinadlezhnosti / Yakuba Yu.F. [i dr.] // Analitika i kontrol'. 2014. T. 18. № 4. S. 344-372.

17. Sobolev E. M. Tekhnologiya natural'nyh i special'nyh vin. Majkop: GURIPP «Adygeya», 2004. 400 s.

18. Sumby K. M., Grbin P. R., Jiranek V. Microbial modulation of aromatic esters in wine:Current knowledge and future prospects // Food Chemistry. 2010. Vol. 121. P. 1-16.

19. Kishkovskij Z.N., Merzhanian A.A. Tekhnologiya vina. M.: Legkaya i pishch. prom-t', 1994. $504 \mathrm{~s}$.

20. Yang E. Dourtoglou Approaches to outline the aromatic profile of Kyoho wines from South Korea // Bio web f Conferences. 40 th World Congressof Vine and Wine. 2017. Vol. 9. P. 2034-2038.

21. Duan L. L. Effects of AddingUnsaturated Fatty Acids on Fatty AcidComposition of Saccharomyces cerevisiaeand Major Volatile Compounds in Wine // S. Afr. J. Enol. Vitic. 2015. Vol. 36. P. 285-295.

22. Yakimenko E.N., Ageeva N.M., Yakuba Yu.F. Biohimicheskij sostav stolovyh vin $\mathrm{v}$ zavisimosti ot sorta vinograda // Nauchnye trudy SKFNCSVV. T. 25. Krasnodar: SKFNCSVV, 2019. S. 196-200.

23. Il'chibaeva I. B. Tekhnologicheskoe znachenie organicheskih soedinenij v vinodelii. Novocherkassk: YuRGTU, 2007. 112 s. 